\title{
Efficacy of Bio-pesticides against Diamond Backmoth on Broccoli at Ambikapur, (Chhattisgarh)
}

\author{
Saurabh Singh", P. K. Bhagat, G. P. Painkra and K. L. Painkra \\ Department of Entomology, IGKV, Raj Mohini Devi College of Agriculture and Research \\ Station, Chhattisgarh, India \\ *Corresponding author
}

\section{Keywords}

Azadirachtin, Brocolli, Biopesticides, Efficacy, population

Article Info

Accepted: 10 January 2021 Available Online: 10 February 2021
The present investigation entitled "Population dynamics and management of major insectpests of broccoli (Brassica oleracea var italica) with special reference to diamondback moth (Plutella xylostella L)" was conducted in the Research Cum Instructional Farm of Raj Mohini Devi College of Agriculture and Research Station, Ambikapur (C.G.) during rabi 2019-20. The insect pests aphids, DBM, tobacco leaf eating caterpillar, Helicoverpa armigera, leaf webber, sawfly and whitefly were reported as major insect pests on brocolli crop. The peak population of aphids (30.60/leaf), DBM (9.00/ plant), tobacco leaf eating caterpillar (2.73/ plant), Helicoverpa armigera (1.67/leaf), leaf webber (3.07/leaf), sawfly (3.33/leaf) and whitefly (14.93/leaf) were seen during second fortnight of January, first fortnight of February, first fortnight of February, first fortnight of February, second fortnight of January, first fortnight of February and second fortnight of January, respectively. The incidence of lady bird beetle initiated from second fortnight of December (0.33/leaf) with gradual increase and attained its peak in second fortnight of January (1.13/leaf). The population gradual decreased and reached its minimum during second fortnight of March (0.27/leaf). During the period of observations it was observed that the maximum per cent plant infestation by diamond-back moth in broccoli were found in $18^{\text {th }}$ march $(71.1 \%)$ followed by $4^{\text {th }}$ march $(68.9 \%)$. Where as during $25^{\text {th }}$ December minimum per cent plant infestation $(8.9 \%)$ were observed. The overall mean larval population recorded after first and second spray revealed that T6 (spinosad 45\% SC) found best treatment in respect to other treatments because it's recorded lowest mean larval population i.e. 4.54 larvae/plant followed by NSKE 5\% (6.15 larvae/plant), Bacillus thuringiensis $2 \times 10^{8}$ (6.73 larvae/plant), Metarhizium anisopliae $2.8 \times 10^{6}$ (6.77 larvae/plant), Azadirachtin 1500ppm(6.95 larvae/plant), Karanj oil 1\% (7.10 larvae/plant), The highest mean larval population was observed in control plot (12.74 larvae/plant).

\section{Introduction}

Broccoli (Brassica oleracea var. italica), belongs to family cruciferae, is a member of Cole group having 18 chromosomes $(2 \mathrm{n}=18$, $x=9)$. The term 'Cole' originated from the word Colewort meaning wild cabbage. While, the broccoli derived its name from the Latin word Brachium meaning an arm or branch (Dixon 2007). The species originated in 
Mediterranean region. Area under cauliflower and broccoli is about 13 lakh hectare in the world with annual production of about 2 crore metric tons (Anonymous 2014. In India it is generally grown in hilly areas of Himachal Pradesh, Uttar Pradesh, Jammu and Kashmir, Nilgiri Hills and Northern plains. In India cauliflower and broccoli are grown over an area of 4 lakh ha with annual production 85 lakh MT. Broccoli is known for its better taste, flavor and high nutritive and medicinal value. In the world market, about 40 per cent is marketed as fresh and remaining 60 per cent as frozen. It is used as curries, sauces, stir fried, boiled, steamed, soups, pickles and also eaten as a salad and cooked as a single or mixed vegetable with potato (Thamburaj and Singh 2001). Fresh broccoli contains $89.1 \%$ water, $2500 \mathrm{IU}$ vitamin A and $113 \mathrm{mg}$ vitamin C per $100 \mathrm{~g}$ by weight (Dhaliwal 2012).

The pest complex is a major menace in cole crops production. Diamondback moth is a major pest of cruciferous vegetables crop like cabbage, cauliflower, broccoli, and rapeseed and enjoys worldwide distribution (Chelliah and Srinivasan, 1986). The DBM is a serious pest of crucifer vegetables throughout Asia (NRI, 1991; Zhang, 1994) and it is regular pest of cauliflower (Singh,1980).In India, it was first recorded in 1914 on crucifer vegetable (Fletcher, 1914). Economic significance and remunerative nature of the cole crops in short span have compelled the growers to adopt intensive vegetable cultivation. It has been estimated that the insect pests are responsible for reducing more than 40 percent yield in vegetables. Among these the DBM is the most devastating and cosmopolitan pests of crucifer vegetable (CIE, 1967).

The pest is found to be active from July to April with two peak periods, one during September when up to 38 percent are infested and the other during December to February when 23 to 37.9 percent cauliflower, 27 to 49 percent cabbage and 27 to 29 percent radish plant are infested (Chaudhary and Rawat, 1967). Diamond-back moth. P. xylostella (L.) is a major insect pest of crucifers vegetables (Brassica sp.) including cabbage, broccoli, cauliflower, kale, kohlrabi. Chinese cabbage and Brussels sprouts worldwide.

\section{Materials and Methods}

The experiment was laid out in a randomized block design (RBD) with 7 treatments (Table $1)$ and replicated three times. The plot size was $4 \times 4 \mathrm{~m}^{2}$ and the spacing $60 \mathrm{~cm} \times 45 \mathrm{~cm}$, on the of variety "Palam samridhi" used. All the recommended agronomic practices were adopted during the experimentation. The required quantity of spray solution was calibrated and spraying done by knapsack sprayer. The first spray of bio-insecticides was done at the initiation of pest infestation and second spray was done at 15 days after first spray.

\section{Treatment details}

\begin{tabular}{|c|c|c|}
\hline Treatment & Name of bio-pesticides & Dose (g or ml /lit) \\
\hline $\mathbf{T}_{\mathbf{1}}$ & Bacillus thuringiensis $2 \times 10^{8}$ & $0.4 \mathrm{ml}$ \\
\hline $\mathbf{T}_{\mathbf{2}}$ & Azadirachtin (1500 ppm) & $3 \mathrm{ml}$ \\
\hline $\mathbf{T}_{\mathbf{3}}$ & Metarhizium anisopliae $2.8 \times 10^{6}$ & $2.5 \mathrm{ml}$ \\
\hline $\mathbf{T}_{\mathbf{4}}$ & NSKE 5\% & $5 \mathrm{ml}$ \\
\hline $\mathbf{T}_{\mathbf{5}}$ & Karanj oil 1\% & $10 \mathrm{ml}$ \\
\hline $\mathbf{T}_{\mathbf{6}}$ & Spinosad 45\%SC & $0.5 \mathrm{ml}$ \\
\hline $\mathbf{T}_{\mathbf{7}}$ & Control & - \\
\hline
\end{tabular}


Pretreatment observations were recorded from randomly selected 5 plants for each treatment. Post treatment observations were recorded at 1, 3, 7 and 15 days of each spray.

The yield of curds was recorded from each plot in each replication separately. The data obtained from the individual plant observations from RBD experiment was analyzed statistically as per the standard procedure.

\section{Results and Discussion}

Pre treatment observation before first spray

The larval population of diamond back moth was counted at randomly selected five plants. The pre treatment mean larval population showed in table 4.1 varied between 8.9 to 10.1 larvae /plant.

\section{Observation after first day of first spray}

The larval population recorded after one day of spraying indicated that the mean population of insect varied between 7.3to10.9 larvae/plant.

The lowest mean larval population was recorded in T6 (Spinosad 45\% SC) i.e. 7.3 larvae/plant followed by NSKE 5\% (7.6 larvae/plant), Bacillus thuringiensis $2 \times 10^{8}$ (8.1 larvae/plant), Azadirachtin 1500ppm (8.9 larvae/plant), Metarhizium anisopliae 2.8×10 ${ }^{6}$ and Karanj oil 1\% (9.1 larvae/plant). The maximum mean larval population was recorded in control plot (10.9 larvae/plant).

\section{Observation after third day of first spray}

The larval population recorded after third day of spraying indicated that the mean population of insect varied between 4.7to11.3 larvae/plant. The lowest mean larval population was recorded in T6 (Spinosad 45\% SC)i.e. 4.7 larvae/plant followed by Metarhizium anisopliae $2.8 \times 10^{6}(6.3$ larvae/plant), Karanj oil 1\% (6.6 larvae/plant), NSKE 5\% (6.8larvae/plant), Bacillus thuringiensis $2 \times 10^{8}$ (6.9 larvae/plant) and Azadirachtin 1500ppm (7.1 larvae/plant). The maximum mean larval population was recorded in control plot (11.3 larvae/plant).

\section{Observation after seven day of first spray}

The larval population recorded after seven day of spraying indicated that the mean population of insect varied between 3.1to12.1 larvae/plant.

The lowest mean larval population was recorded in T6 (Spinosad 45\% SC) i.e. 3.1 larvae/plant followed by NSKE 5\% (6.1 larvae/plant) and Bacillus thuringiensis $2 \times 10^{8}$ (6.1 larvae/plant), Karanj oil $1 \% \quad(6.2$ larvae/plant), Azadirachtin 1500ppm (6.5 larvae/plant), Metarhizium anisopliae $2.8 \times 10^{6}(6.9$ larvae/plant). The maximum mean larval population was recorded in control plot (12.1 larvae/ plant).

\section{Observation after fifteen day of first spray}

The larval population recorded after fifteen day of spraying indicated that the mean population of insect varied between 1.9to12.3 larvae/plant.

The lowest mean larval population was recorded in T6 (Spinosad 45\% SC) i.e. 1.9 larvae/plant followed by NSKE 5\% (4.2 larvae/plant), Karanj oil 1\% (4.4 larvae/plant), Bacillus thuringiensis $2 \times 10^{8} \quad$ (5.0 larvae/ plant), Azadirachtin 1500ppm (5.1 larvae/ plant), Metarhizium anisopliae $2.8 \times 10^{6}$ (5.3 larvae/plant).

The maximum mean larval population was recorded in control plot (12.3 larvae/plant). 
Table.1 Evaluation of biopesticides insecticides against broccoli diamond back moth during Rabi 2019-20

\begin{tabular}{|c|c|c|c|c|c|c|c|c|c|c|c|c|}
\hline \multirow[t]{2}{*}{ S.No. } & \multirow[t]{2}{*}{ Treatments } & \multicolumn{5}{|c|}{ First spray } & \multicolumn{5}{|c|}{ Second spray } & \multirow{2}{*}{$\begin{array}{l}\text { Overall } \\
\text { mean }\end{array}$} \\
\hline & & $\begin{array}{c}\text { Pre } \\
\text { Treat. }\end{array}$ & 1DAS & 3DAS & 7DAS & 15DAS & $\begin{array}{c}\text { Pre } \\
\text { Treat. }\end{array}$ & 1DAS & 3DAS & 7DAS & 15DAS & \\
\hline 1 & Bacillus thuringiensis $0.4 \mathrm{ml}$ & $\begin{array}{c}8.9 \\
(3.15)^{*}\end{array}$ & $\begin{array}{c}8.1 \\
(3.01)\end{array}$ & $\begin{array}{c}6.9 \\
(2.82)\end{array}$ & $\begin{array}{l}6.1 \\
(2.7)\end{array}$ & $\begin{array}{c}5.0 \\
(2.44) \\
\end{array}$ & $\begin{array}{c}8.3 \\
(3.0)\end{array}$ & $\begin{array}{c}8.3 \\
(3.04)\end{array}$ & $\begin{array}{c}5.7 \\
(2.59)\end{array}$ & $\begin{array}{c}5.1 \\
(2.46)\end{array}$ & $\begin{array}{c}5.0 \\
(2.44) \\
\end{array}$ & 6.73 \\
\hline 2 & Azadirachtin (1500ppm) $2.5 \mathrm{ml}$ & $\begin{array}{c}9.7 \\
(3.27)\end{array}$ & $\begin{array}{c}8.9 \\
(3.15)\end{array}$ & $\begin{array}{c}7.1 \\
(2.84)\end{array}$ & $\begin{array}{c}6.5 \\
(2.74)\end{array}$ & $\begin{array}{c}5.1 \\
(2.47)\end{array}$ & $\begin{array}{c}6.5 \\
(2.72)\end{array}$ & $\begin{array}{c}8.6 \\
(3.09)\end{array}$ & $\begin{array}{l}6.3 \\
(2.7)\end{array}$ & $\begin{array}{c}6.0 \\
(2.64)\end{array}$ & $\begin{array}{c}4.7 \\
(2.37)\end{array}$ & 6.95 \\
\hline 3 & $\begin{array}{l}\text { Metarhizium anisopliae } \\
2.5 \mathrm{ml}\end{array}$ & $\begin{array}{c}9.3 \\
(3.21) \\
\end{array}$ & $\begin{array}{c}9.1 \\
(3.18)\end{array}$ & $\begin{array}{c}6.3 \\
(2.69) \\
\end{array}$ & $\begin{array}{c}6.9 \\
(2.8)\end{array}$ & $\begin{array}{c}5.3 \\
(2.5)\end{array}$ & $\begin{array}{c}6.0 \\
(2.64)\end{array}$ & $\begin{array}{c}7.1 \\
(2.85)\end{array}$ & $\begin{array}{c}6.2 \\
(2.67)\end{array}$ & $\begin{array}{c}6.1 \\
(2.67)\end{array}$ & $\begin{array}{c}5.3 \\
(2.51) \\
\end{array}$ & 6.77 \\
\hline 4 & $\begin{array}{l}\text { NSKE } \\
5 \mathrm{ml}\end{array}$ & $\begin{array}{c}8.9 \\
(3.14)\end{array}$ & $\begin{array}{c}7.6 \\
(2.93)\end{array}$ & $\begin{array}{c}6.8 \\
(2.79)\end{array}$ & $\begin{array}{c}6.1 \\
(2.67)\end{array}$ & $\begin{array}{c}4.2 \\
(2.27)\end{array}$ & $\begin{array}{c}6.0 \\
(2.62)\end{array}$ & $\begin{array}{c}8.1 \\
(3.01)\end{array}$ & $\begin{array}{c}4.9 \\
(2.43)\end{array}$ & $\begin{array}{c}4.8 \\
(2.4)\end{array}$ & $\begin{array}{c}4.1 \\
(2.24)\end{array}$ & 6.15 \\
\hline 5 & $\begin{array}{l}\text { Karanj oil 1\% } \\
10 \mathrm{ml}\end{array}$ & $\begin{array}{c}10.1 \\
(3.33)\end{array}$ & $\begin{array}{c}9.1 \\
(3.18)\end{array}$ & $\begin{array}{c}6.6 \\
(2.76)\end{array}$ & $\begin{array}{c}6.2 \\
(2.64)\end{array}$ & $\begin{array}{c}4.4 \\
(2.31)\end{array}$ & $\begin{array}{c}7.5 \\
(2.91)\end{array}$ & $\begin{array}{c}8.7 \\
(3.11)\end{array}$ & $\begin{array}{c}6.6 \\
(2.74)\end{array}$ & $\begin{array}{c}6.7 \\
(2.74)\end{array}$ & $\begin{array}{c}5.1 \\
(2.45)\end{array}$ & 7.10 \\
\hline 6 & $\begin{array}{l}\text { Spinosad } 45 \% \text { SC } \\
0.5 \mathrm{ml}\end{array}$ & $\begin{array}{c}9.9 \\
(3.30)\end{array}$ & $\begin{array}{c}7.3 \\
(2.87)\end{array}$ & $\begin{array}{c}4.7 \\
(2.38)\end{array}$ & $\begin{array}{c}3.1 \\
(2.01)\end{array}$ & $\begin{array}{c}1.9 \\
(1.68)\end{array}$ & $\begin{array}{c}4.9 \\
(2.41)\end{array}$ & $\begin{array}{c}4.4 \\
(2.31)\end{array}$ & $\begin{array}{c}4.2 \\
(2.27)\end{array}$ & $\begin{array}{c}3.3 \\
(2.06)\end{array}$ & $\begin{array}{c}1.9 \\
(1.69)\end{array}$ & 4.54 \\
\hline 7 & Control & $\begin{array}{c}9.8 \\
(3.29)\end{array}$ & $\begin{array}{c}10.9 \\
(3.45)\end{array}$ & $\begin{array}{c}11.3 \\
(3.50)\end{array}$ & $\begin{array}{c}12.1 \\
(3.61)\end{array}$ & $\begin{array}{c}12.3 \\
(3.64)\end{array}$ & $\begin{array}{c}13.4 \\
(3.78)\end{array}$ & $\begin{array}{c}14.1 \\
(3.87)\end{array}$ & $\begin{array}{c}14.2 \\
(3.88)\end{array}$ & $\begin{array}{c}14.6 \\
(3.93)\end{array}$ & $\begin{array}{c}14.7 \\
(3.95)\end{array}$ & 12.74 \\
\hline & C.D. at $5 \%$ & N/A & 0.239 & 0.143 & 0.42 & 0.251 & 0.473 & 0.416 & 0.38 & 0.439 & 0.229 & - \\
\hline & SEm & 0.088 & 0.077 & 0.046 & 0.135 & 0.08 & 0.152 & 0.134 & 0.122 & 0.141 & 0.074 & - \\
\hline
\end{tabular}

* Figures in parenthesis are square root transformation

Table.2 Effect of biopesticides on yield parameters of brocolli var. "palam samridhi” during Rabi, 2019-20

\begin{tabular}{|l|c|c|c|c|}
\hline \multicolumn{1}{|c|}{ Treatment } & $\begin{array}{c}\text { Dose } \\
\text { (g or ml /lit.) }\end{array}$ & $\begin{array}{c}\text { Yield } \\
\text { (tonn./ha.) }\end{array}$ & $\begin{array}{c}\text { Increased } \\
\text { over control }\end{array}$ & $\begin{array}{c}\text { Per cent } \\
\text { increased }\end{array}$ \\
\hline Bacillus thuringiensis & $0.4 \mathrm{ml}$ & 21.60 & 4.23 & 24.35 \\
\hline Azadirachtin (1500ppm) & $2.5 \mathrm{ml}$ & 19.03 & 1.66 & 9.55 \\
\hline Metarhizium anisopliae & $2.5 \mathrm{ml}$ & 20.96 & 3.59 & 20.66 \\
\hline NSKE & $5 \mathrm{ml}$ & 19.65 & 2.28 & 13.12 \\
\hline Karanj oil 1\% & $10 \mathrm{ml}$ & 18.49 & 1.12 & 6.44 \\
\hline Spinosad 45\%SC & $0.5 \mathrm{ml}$ & 23.27 & 5.9 & 33.97 \\
\hline Control & - & 17.37 & - & - \\
\hline
\end{tabular}


Fig.4.1 Mean larval population of diamond back moth after first spray

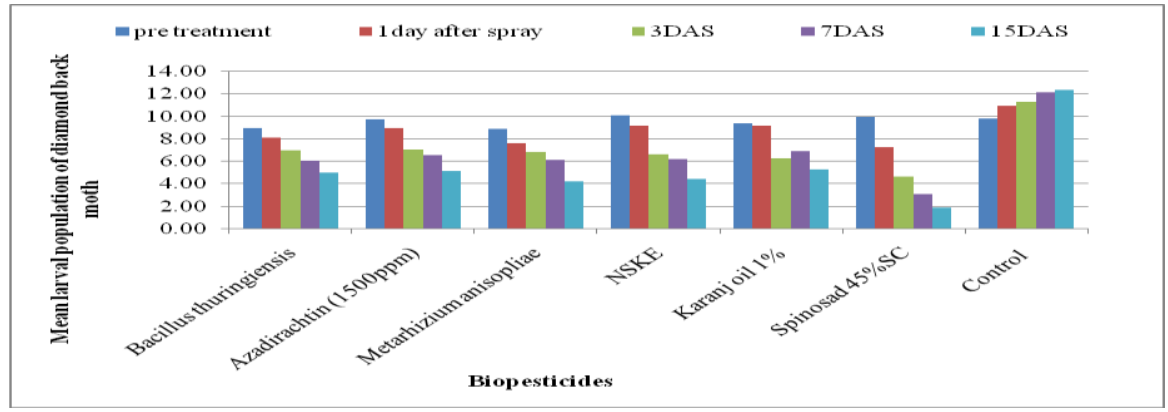

Fig.4.2 Mean larval population of diamond back moth after second spray

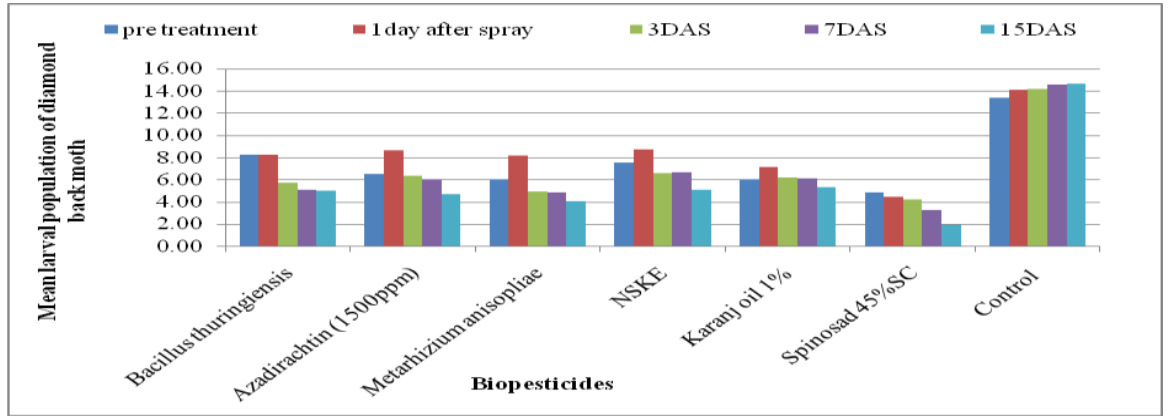

\section{Observation after first day of second spray}

The larval population recorded after first day of spraying indicated that the mean population of insect varied between 4.4 to14.1 larvae/plant. The lowest mean larval population was recorded in T6 (Spinosad 45\% SC) i.e. 4.4 larvae/plant followed by Metarhizium anisopliae $2.8 \times 10^{6}(7.1$ larvae/plant), NSKE 5\% (8.1 larvae/plant), Bacillus thuringiensis $2 \times 10^{8} \quad(8.3$ larvae/plant), Azadirachtin 1500ppm (8.6 larvae/plant), Karanj oil 1\% (8.7 larvae/plant). The maximum mean larval population was recorded in control plot (14.1larvae/plant).

\section{Observation after third day of second spray}

The larval population recorded after third day of spraying indicated that the mean population of insect varied between 4.2to14.2 larvae/plant. The lowest mean larval population was recorded in T6 (Spinosad 45\% SC) i.e. 4.2 larvae/plant followed by NSKE 5\% (4.9 larvae/plant), Bacillus thuringiensis $2 \times 10^{8} \quad(5.7 \quad$ larvae/plant), Metarhizium anisopliae $\quad 2.8 \times 10^{6}(6.2 \quad$ larvae/plant $)$, Azadirachtin 1500ppm (6.3 larvae/plant), Karanj oil $1 \% \quad$ (6.6 larvae/plant). The maximum mean larval population was recorded in control plot (14.2larvae/plant).

Observation after seven day of second spray

The larval population recorded after seven day of spraying indicated that the mean population of insect varied between 3.3to14.6 larvae/plant. The lowest mean larval population was recorded in T6 (Spinosad 45\% SC) i.e. 3.3 larvae/plant followed by NSKE 5\% (4.8 larvae/plant), Bacillus thuringiensis $2 \times 10^{8} \quad(5.1$ larvae/plant), Azadirachtin $1500 \mathrm{ppm}$ (6.0 larvae/plant), Metarhizium anisopliae $2.8 \times 10^{6}(6.1$ larvae/plant), Karanj 
oil 1\% (6.7 larvae/plant). The maximum mean larval population was recorded in control plot (14.6 larvae/plant).

\section{Observation after fifteen day of second spray}

The larval population recorded after fifteen day of spraying indicated that the mean population of insect varied between 1.9 to 14.7 larvae/plant. The lowest mean larval population was recorded in T6 (Spinosad 45\% SC) i.e. 1.9 larvae/plant followed by NSKE 5\% (4.1 larvae/plant),Azadirachtin 1500ppm (4.7 larvae/plant), Bacillus thuringiensis $2 \times 10^{8}$ (5.0 larvae/plant), Karanj oil 1\% (5.1 larvae/plant), Metarhizium anisopliae $2.8 \times 10^{6}(5.3$ larvae/plant), The maximum mean larval population was recorded in control plot (14.7 larvae/plant).

\section{Overall mean population after first and second spray}

The overall mean larval population recorded after first and second spray revealed thatT6 (Spinosad 45\% SC) found best treatment in respect to other treatments because it's recorded lowest mean larval population i.e. 4.54 larvae/plant followed by NSKE 5\% (6.15 larvae/plant), Bacillus thuringiensis $2 \times 10^{8}$ (6.73 larvae/plant), Metarhizium anisopliae $2.8 \times 10^{6}(6.77$ larvae/plant), Azadirachtin 1500ppm(6.95 larvae/plant), Karanj oil $1 \%$ (7.10 larvae/plant), The maximum mean larval population was recorded in control plot (12.74 larvae/plant).

The present findings are agreement with the findings ofDebbarma et al., (2017) conduct a field trial to evaluate the efficacy of certain bio-rational insecticides against Plutella xylostella and Pieris brassicae on a crop variety "Pride of India". The studied revealed that Spinosad (Saccharopolyspora spinosa) 2.5 SC @ $500 \mathrm{ml} / \mathrm{ha}$ was found most effective to control both these pests with lower mean leaf damage by 14.22 percent and 24.30 percent respectively. It was followed by myco-jaal (Beauveria bassiana) 10 SC @ 500 $\mathrm{ml} /$ ha with 15.11 percent and 26.59 percent and differs significantly from untreated control 69.18 percent. The present findings are also agreement with the findings of Meena and Singh., (2003) reported that spinosad 45 SC @ 0.002 percent proved to be the most effective insecticide in reducing the larval population of $P$. xylostella among all the tested insecticides and recorded highest yield of $233.50 \mathrm{q} / \mathrm{ha}$.

In conclusion the overall mean larval population recorded after first and second spray revealed that T6 (Spinosad 45\% SC $0.5 \mathrm{ml}$ ) found best treatment in respect to other treatments because its recorded lowest mean larval population i.e. 4.54 larvae/plant followed by NSKE $5 \mathrm{ml}$ (6.15 larvae/plant), Bacillus thuringiensis $0.4 \quad \mathrm{ml} \quad(6.73$ larvae/plant), Metarhizium anisopliae $2.5 \mathrm{ml}$ (6.77 larvae/plant), Azadirachtin (1500ppm) $2.5 \mathrm{ml}$ (6.95 larvae/plant), Karanj oil 1\% 10 $\mathrm{ml}$ (7.10 larvae/plant), The maximum mean larval population was recorded in control plot (12.74 larvae/plant).

\section{References}

Aiswarya, V.A., Bhosle, B.B. and Bhede, B.V. 2016. Population dynamics of major lepidopteran insect pests of cabbage, International Journal of Current Microbiology and Applied Sciences, Pp. 236-239.

Anonymous. Indian Horticulture Database 2017-18.

Anonymous. Food and Agriculture Organization. FAO. Org. 2012.

Aslam, M. 2005. Integrated pest management of aphids in canola. Final Report ALP Project, PARC- Bahauddin Zakariya University, Multan, 62. 
Joshi, Neelam, Shenhmar, Manider, Brar, K.S. And Bakhetia, D.R.C. 1999. Comparative Efficacy Of Some Bacillus Thuringiensis Berliner Formulations Against Plutella Xylostella On Cabbage. J. Insect Science, 12(2): 142148.

Maity, L. Padhi, G. Samanta, A. 2018. Population dynamics and management of diamond back moth Plutella Xylostella (L.) in cabbage ecosystem of West Bengal. International Journal of Chemical Studies, 6(1): 381-385.

Meena, M.K., Sharma, U.S. 2003. Seasonal incidence and assessment of some microbial insecticides against diamondback moth, Plutella Xylostella (Linn.) in cabbage. Journal of Applied Zoological Research, 14(1):61-62.

Palande, P.R., Pokharkar, D.S. and Nalawade, P.S. 2004. Seasonal incidence of cabbage pests in relation to weather. Pest Management in Horticultural Ecosystems, 10(2):151-156.

Patel, Lakshman, Konar, Amitava and Saha. 2015. Seasonal incidence and insecticidal efficacy against diamond back moth and aphid of broccoli. International Journal of Tropical Agriculture, 33(4): 2459-2465.
Raja, M., William, S.J. and David, B.V. 2014. Population dynamics of key insect pests of cabbage in Tamil Nadu. Indian Journal of Entomology, 76(1):01-07.

Rao, G.R., Raghavaiah, G and Nagalingam, B. 1993. Effect of botanicals on certain behavioral responses and on the growth inhibitor of Spodoptera Litura in: Botanical Pesticides in Integrated Pest Management, Pp.175-182.

Rohilla, H.R., Singh, M., Kalra, U.K. And Kharub, S.S.1987. Losses caused by cabbage aphid (Brevicoryne Brassicae Linn.) in different brassica genotypes. In: Proceedings, 7th International Rapeseed Congress, Poland. 5:10771083.

Tambe, A.B., Kadam, U.K. and Darekar, K.S. 1997. Bioefficacy Of Difel ES (B.T.) against diamond back moth Plutella Xylostella L. on cabbage Pestology,21(4): 42- 44.

Venugopal, U., Ashwani, K., Shankar, H., Prasad, D., and Rajesh, B. 2017. Seasonal incidennce of diamondback moth on cabbage under allahabad condition. Journal of Entomology and Zoology Studies, 5(6): 2477- 2480.

\section{How to cite this article:}

Saurabh Singh, P. K. Bhagat, G. P. Painkra and Painkra, K. L. 2021. Efficacy of Bio-pesticides against Diamond Backmoth on Broccoli at Ambikapur, (Chhattisgarh). Int.J.Curr.Microbiol.App.Sci. 10(02): 20-26. doi: https://doi.org/10.20546/ijcmas.2021.1002.003 